\title{
Pozorny moduł Younga klejów epoksydowych w połączeniu klejowym metali
}

\author{
The apparent Young's modulus of epoxy adhesives \\ in metal-metal adhesive joints
}

\begin{abstract}
Streszczenie
W analizie modelowej MES jednym z istotnych elementów jest dokładne określenie stałych materiałowych takich jak moduł Younga czy współczynnik Poissona. Z reguły określa się je w standardowych próbach na próbkach „wiosełkowych" lub przyjmuje na podstawie dostępnej literatury. W przypadku połączeń klejowych sprawa jest bardziej skomplikowana. Klej w stanie płynnym, w kontakcie z powierzchnią metalu, podlega silnemu oddziaływaniu pola sił fizysorpcyjnych i chemisorpcyjnych na granicy faz. W efekcie w bezpośredniej strefie granicznej następuje specyficzne porządkowanie struktury co skutkuje zmianą właściwości tej strefy w stanie utwardzonym. Grubość tej strefy zależy od wielu czynników, najczęściej zmiana tych właściwości przejawia się wzrostem sztywności utwardzonego kleju w tej strefie. Zjawisko to znane jest jako "pozorny" moduł Younga. W sytuacji, gdy grubość warstwy kleju jest mała, a tak z reguły jest w przypadku połączeń metali, zjawisko to może w istotny sposób zwiększać niepewność otrzymanych wyników symulacji. W pracy przedstawiono badania porównawcze polegające na wyznaczeniu współczynnika sprężystości wzdłużnej kleju dla próbek „wiosełkowych” oraz kleju w spoinie klejowej dla próbek „przekładkowych”. Wyznaczono różnicę w wartości modułu Younga kleju epoksydowego oraz spoiny klejowej. Rozważano wpływ tej różnicy na stopień zgodności otrzymywanych wyników symulacji MES z wynikami badań niszczących.
\end{abstract}

Słowa kluczowe: połączenie klejowe; pozorny moduł Younga; klejenie; adsorpcja

\begin{abstract}
In FEM analysis one of crucial elements is to accurately determine material constants like Young's modulus or Poisson's ratio. In general these constants are identified in standard tests on dumbbell-shaped samples or assumed based on available literature. In case of adhesive joints issue is much more complicated. Adhesive in its uncured state, in contact with surface of the metal, is subjected to impact of physisorption and chemisorption forces at the phase boundary. In the effect of this in the direct boundary zone occurs specific structure ordering, which results in modification of properties of this area in cured state. Thickness of this zone is dependent on various factors, predominantly change of these properties results in increased glue rigidity. This phenomenon is known as "apparent" Young's modulus. In case, where thickness of glue layer is small, as it is typically for adhesive metal joints, this phenomenon might significantly increase uncertainty of the results of the FEM simulation. Comparative studies were shown involving the determination of the elastic modulus of adhesive of the dumbbell samples and an adhesive joint in the interleaved samples. The difference in the value of Young's modulus of adhesive epoxy material and adhesive joint was determined. The impact of this difference on the degree of compliance of FEM simulation in comparison with results of destructive testing was considered.
\end{abstract}

Keywords: adhesive joint; apparent Young's modulus; bonding; adsorption

\section{Wstęp}

Przemysł lotniczy w istotnym stopniu determinuje standardy w zakresie łączenia nowoczesnych materiałów konstrukcyjnych, w szczególności w aspekcie połączeń klejowych. Rozpowszechnienie złączy klejowych spowodowane łatwością aplikacji oraz możliwością łączenia różnych materiałów np. metalu z tworzywem polimerowym, znalazło zastosowanie w budowie maszyn, jak również w budowie statków powietrznych $[1,2]$. Zauważono, że wyznaczanie modułu Younga kleju w statycznej próbie rozciągania tradycyjnej próbki „wiosełkowej", nie uwzględnia zjawisk jakie zachodzą w spoinie podczas utwardzania, a w szczególności spowodowanych kontaktem z elementami klejonymi. Zjawiska te mogą mieć znaczny wpływ na strukturę spoiny w stanie utwardzonym. Dlatego dokładne określenie stałych materiałowych kleju, z uwzględnieniem charakteru eksploatacji spoiny, jest podstawą do przeprowadzenia poprawnej symulacji metodą elementów skończonych. W przypadku połączeń klejowych wyznaczenie prawidłowych wartości modułu Younga czy współczynnika Poissona może

Mgr inż. Kamil Anasiewicz; prof. dr hab. inż. Józef Kuczmaszewski - Politechnika Lubelska.

Autor korespondencyjny/Corresponding author: k.anasiewicz@pollub.pl 
stanowić pewien problem. Klej w stanie płynnym, w kontakcie z powierzchnią metalu, o silnie rozwiniętej powierzchni, jest poddawany oddziaływaniu sił fizysorpcyjnych i chemisorpcyjnych na granicy faz. Adsorpcja fizyczna powoduje zagęszczenie substancji na powierzchni adsorbentu, dzięki działaniu sił przyciągania międzycząsteczkowego. Oddziaływanie to powoduje specyficzne uporządkowanie struktury kleju w strefie przyściennej, która odznacza się odmiennymi własnościami w stosunku do środkowej części spoiny [3,4]. Bardzo często następstwem adsorpcji fizycznej jest adsorpcja chemiczna, jednak zjawiska te mogą również występować jednocześnie. Dzieje się to w przypadku gdy zostanie dostarczona wystarczająco wysoka energia aktywacji rzędu 20-80 kJ/mol. Siły wiążące klej w stanie płynnym z powierzchnią adsorbentu są znacznie większe niż w przypadku adsorpcji fizycznej, jednak charakteryzują się mniejszym zasięgiem. Siły te oddziałując na cząstki żywicy epoksydowej powodują ich koncentrację $[4,5]$. W pewnym zakresie zastosowań oraz grubości spoin klejowych zmiany te mogą powodować błędy w procesie projektowania połączeń klejowych oraz niedokładności w obliczaniu ich wytrzymałości. Zakłada się, że dla spoin o małej grubości, umocnienie w strefie przyściennej może mieć znaczny wpływ na wytrzymałość połączenia [6].

\section{Badania eksperymentalne}

Badania eksperymentalne polegały na wykonaniu dwóch typów próbek, przeprowadzeniu próby rozciągania próbek „wiosełkowych" i odrywania próbek „przekładkowych” oraz analizie wyników. Schemat metodologii badania przedstawiono na rysunku 1.

Wyznaczenie współczynnika sprężystości wzdłużnej spoiny klejowej jest kłopotliwe z uwagi na jej małą grubość.
Założono że zjawisko umocnienia kleju w obrębie strefy przyściennej klejonych elementów będzie trudne do zaobserwowania, dlatego badana próbka została uformowana w postaci konstrukcji przekładkowej blach klejonych naprzemiennie (rys. 2.). Zwiększenie ilości łączonych elementów pozwoliło na pełniejszą obserwację powstawania zjawiska pozornego modułu Younga [5,6]. Do badań przygotowano 5 próbek przekładkowych w formie stosu sklejonych elementów metalowych oraz 6 odlewanych próbek wiosełkowych wg PN-EN ISO 527-4:2000 [7]. Próbki przekładkowe były wykonane jako połączenia klejowe zestawu (stosu) 30 stalowych blach nierdzewnych z materiału X5CrNi18-10, 1.4301 (wg PN-EN 10088-1:2007) o przekroju poprzecznym $8 \times 10 \mathrm{~mm}$ i wysokości łącznej $58 \mathrm{~mm}$.

Nominalna grubość blachy, równa $2 \mathrm{~mm}$, została zmniejszona w wyniku procesu przygotowania powierzchni do klejenia. Powierzchnia próbek przed klejeniem była szlifowana płótnem ściernym o ziarnistości 320. Następnie powierzchnię blach odtłuszczono środkiem odtłuszczającym Loctite 7063. Połączenie zostało wykonane w temperaturze otoczenia wynoszącej $18 \div 20^{\circ} \mathrm{C}$, przy wilgotności względnej $38 \div 40 \%$. Zestaw "stos" blach został sklejony z elementami chwytowymi. Klejenie odbywało się w przyrządzie zapewniającym osiowość oraz jednakowy docisk. Żywica była utwardzana jednostopniowo w temperaturze pokojowej przez okres 7 dni. Badania wytrzymałościowe na rozciąganie przeprowadzono na maszynie wytrzymałościowej Zwick/Roell Z150, zgodnie z zaleceniami PN-EN 15870:2009 [8].

Elementy były klejone przy pomocy kleju epoksydowego Epidian 57/PAC (żywica epoksydowa E57 utwardzana poliaminoamidem C (PAC)) w stosunku masowym 100:70. Grubość spoiny klejowej przyjęto na podstawie dostępnej literatury, której zalecana wartość dla połączeń doczołowych znajdu-

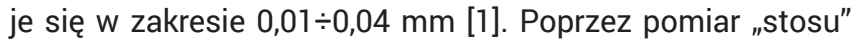

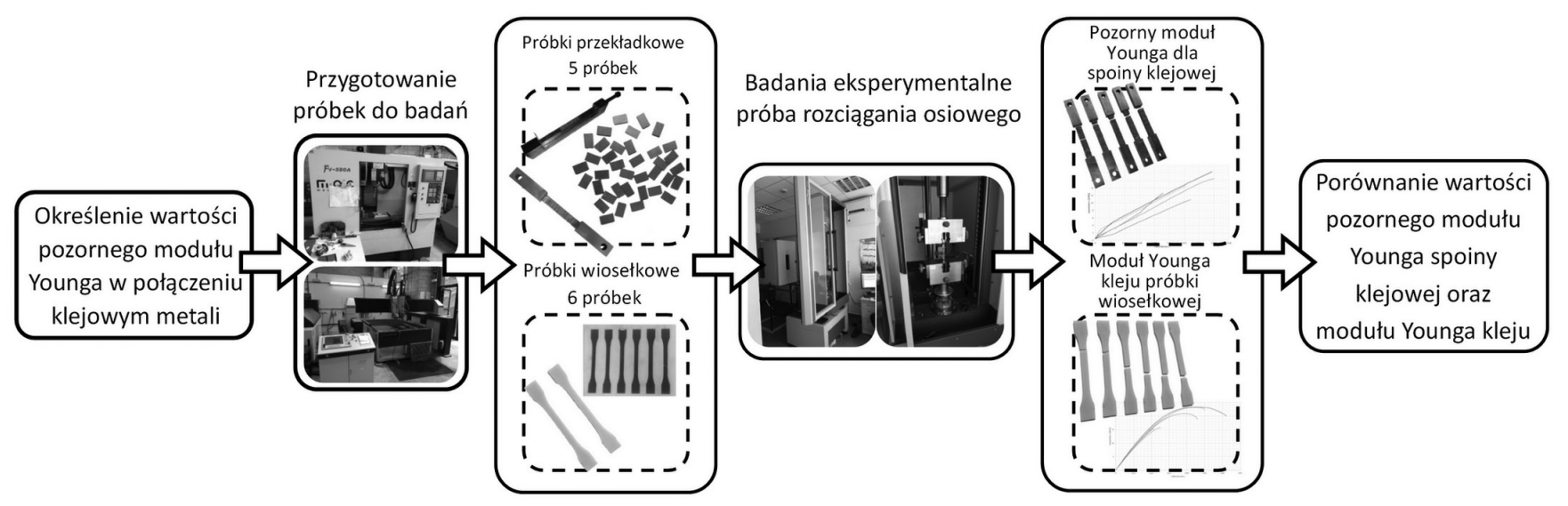

Rys. 1. Schemat blokowy przebiegu doświadczenia

Fig. 1. Flowchart of the research process

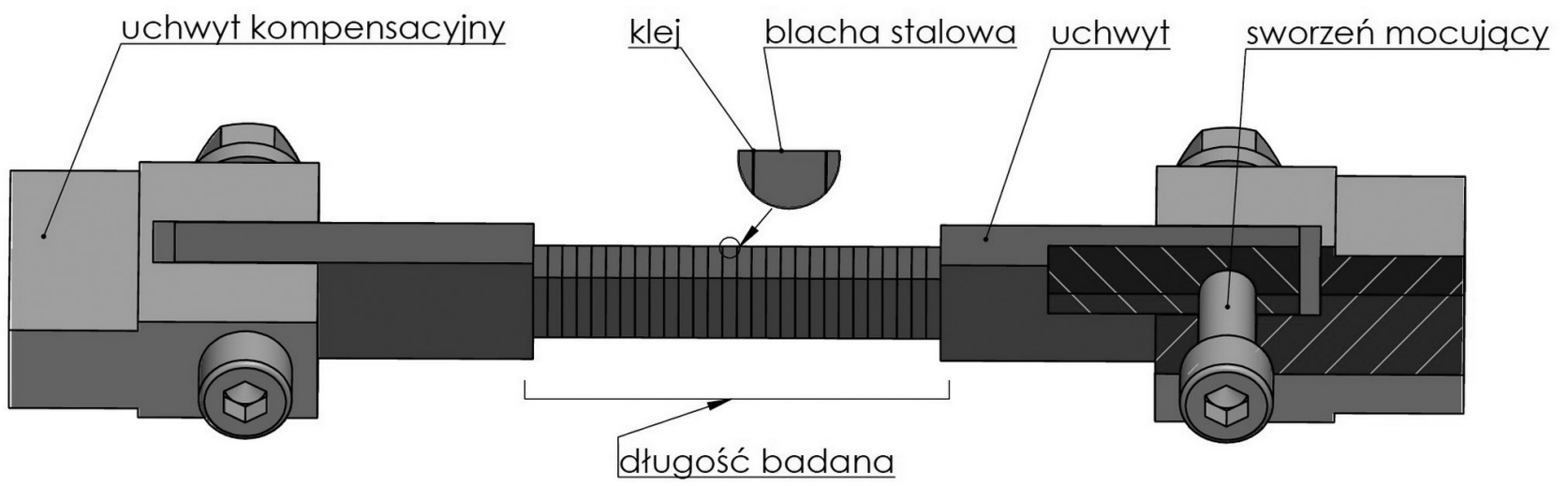

Rys. 2. Kształt próbki przekładkowej do badania pozornego modułu Younga

Fig. 2. The shape of the interleaved sample for testing the apparent elastic modulus 
przed oraz po klejeniu wyliczono grubość pojedynczej spoiny klejowej, której średnia wartość wynosi 0,02548 mm. Łączna rozciągana grubość kleju wynosiła $0,79 \mathrm{~mm}$. W badaniu każdej z próbek rozciągano jednocześnie 31 spoin klejowych, których wydłużenie było mierzone przy pomocy ekstensometru. Szacuje się, że przy tak małym wymiarze spoiny, wzdłuż całej jej grubości zachodzi umocnienie kleju spowodowane oddziaływaniem sił adsorpcji. Stanowisko badawcze z zamontowaną próbką oraz ekstensometrem, umieszczonym na części chwytowej, przedstawiono na rysunku 3.

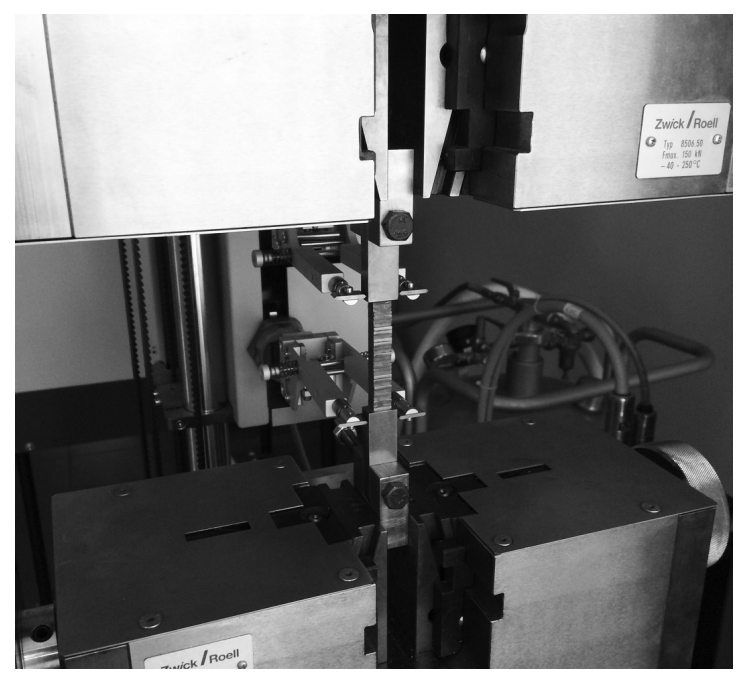

Rys. 3. Stanowisko testowe $\mathrm{z}$ próbką w uchwycie mocującym, z zamontowany ekstensometrem

Fig. 3. The test stand with a sample in the mounting jig, with attached extensometer

W badanej próbce występuje złożony stan naprężenia, związany ze znaczną różnicą pomiędzy wartością modułu Younga kleju oraz elementu klejonego. Odkształcenie względne stali jest pomijalnie małe w porównaniu do odkształcenia kleju, jednak różna długość odcinka pomiarowego kleju, równa $0,79 \mathrm{~mm}$, oraz blach stalowych równa $58 \mathrm{~mm}$, sprawia że należy uwzględnić odkształcenie całkowite blach stalowych w opracowaniu wyników końcowych. Próbki obciążano w zakresie odkształceń sprężystych kleju. Prędkość obciążania próbki wynosiła $1 \mathrm{~mm} / \mathrm{min}$. Jako wynik badania otrzymano charakterystykę zależności naprężenie-odkształcenie. Do celów porównawczych wykonano odlewane próbki wiosełkowe. Próbki odlano w elastycznej formie a następnie obrobiono mechanicznie aby zachować równoległość powierzchni czołowych. Próbki poddano próbie rozciągania zgodnie z PN-EN ISO 527-4:2000 [7].

\section{Wyniki badań}

Prowadzone prace eksperymentalne wykazały zwiększenie wartości modułu Younga utwardzonego kleju w próbkach przekładkowych, klejonych w "stos”, w porównaniu do odlewanych próbek wiosełkowych. Na podstawie wyników próby osiowego rozciągania próbek wiosełkowych, wyznaczono wartość moduł Younga Et kleju Epidian 57/PAC równą $832,6 \mathrm{MPa}$. Odpowiednio na podstawie próby rozciągania próbek przekładkowych wyznaczono Moduł Younga Et o wartości 1870,01 MPa. Wyniki próby rozciągania próbek wiosełkowych przedstawiono na rysunku 4.

Rozrzut w wartościach odkształceń niszczących próbek wiosełkowych może wynikać z wad wewnętrznych struktury kleju, powstałych w procesie przygotowania próbek. Różnice mogą być spowodowane niejednorodnym wymieszaniem żywicy z utwardzaczem, nieuniknionymi wadami struktury

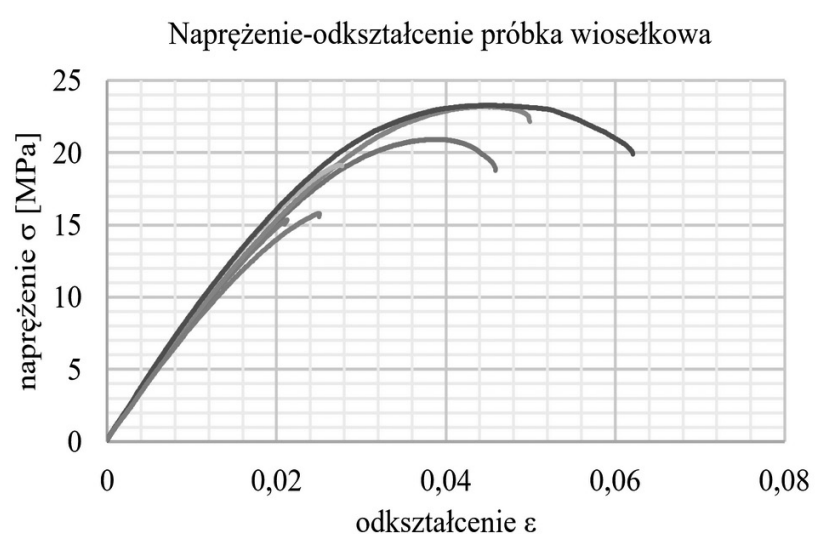

Rys. 4. Krzywe rozciągania kleju Epidian 57/PAC próbek wiosełkowych

Fig. 4. Stress-strain curves of Epidian 57/PAC adhesive of dumbbellshaped samples

i innymi czynnikami. Rozrzut wyników nie wpływa w znacznym stopniu na wartość badań porównawczych.

Umocnienie spoiny klejowej, w obrębie strefy przyściennej, spowodowane działaniem sił fizysorpcyjnych i chemisorpcyjnych na klej w stanie płynnym, dało efekt w postaci wzrostu wartości modułu Younga Et o 124\%. Wartość ta osiąga poziom znacznie większy od wartości opisywanej wzorem [5,9]:

$$
E^{\prime}=E(1-u) /(1+u)(1-2 u)
$$

Krzywe rozciągania próbek przekładkowych, otrzymanych w badaniu (rys. 5.), odznaczają się brakiem strefy odkształceń plastycznych, która jest charakterystyczna dla materiałów polimerowych, z uwagi na ich nieliniowe właściwości [2]. Z wykresów wynika, że zniszczenie próbki następuje jeszcze w zakresie odkształceń sprężystych, jest to związane z małą grubością spoiny klejowej oraz z jej umocnieniem w strefie przyściennej. Indukuje to zniszczenie adhezyjne połączenia, a nie jak w przypadku badania próbek wiosełkowych, kohezyjne. Dodatkowo kształt wykresu jest uwarunkowany faktem, że o zniszczeniu próbki decyduje najsłabsza spoina. Wykres przedstawia zależność naprężenie-odkształcenie dla próbki składającej się z 31 spoin klejowych. Odkształcenie całkowite "stosu" blach i spoin klejowych zostało zredukowane o odkształcenie całkowite blach.

Wykres naprężenie-wydłużenie próbka przekładkowa

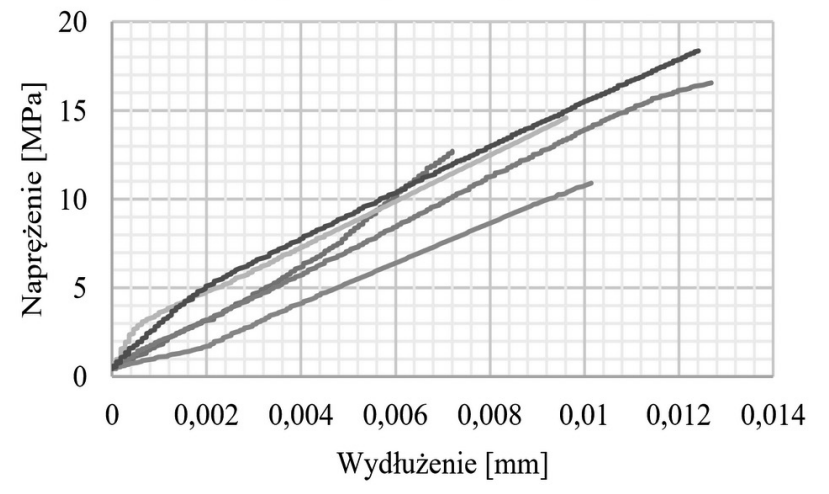

Rys. 5. Krzywe rozciągania spoiny klejowej z kleju Epidian 57/PAC próbek przekładkowych

Fig. 5. Stress-strain curves of adhesive joint of Epidian 57/PAC adhesive of interleaved samples

W postaci graficznej porównanie wartości modułu Younga dla próbek w postaci wiosełek i próbek przekładkowych przedstawiono na rysunku 6.

Sumaryczna średnia grubość spoiny klejowej próbki prze- 
kładkowej wyniosła 0,79 mm. Wartość ta została obliczona poprzez pomiar i porównanie wysokości próbek przed oraz po klejeniu. Na podstawie sumarycznej grubości spoiny obliczono odkształcenie względne kleju. Rysunek 7 przedstawia zestawienie odkształceń względnych próbek przekładkowych i wiosełkowych.

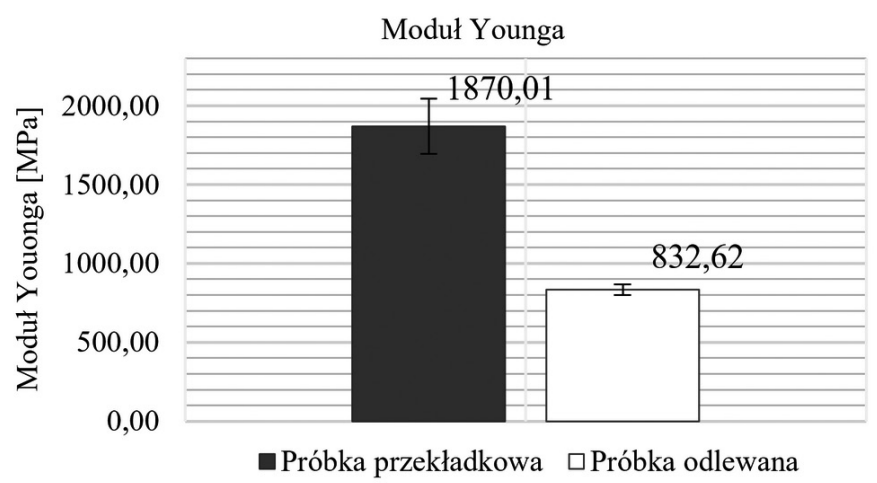

Rys. 6. Porównanie modułu Younga spoiny klejowej oraz kleju w postaci wiosetka

Fig. 6. Comparison of the Young's modulus of adhesive joint and glue in the form of a dumbbell
W oparciu o przedstawione wartości można zauważyć, że odkształcenie względne kleju w spoinie jest znacznie mniejsze w porównaniu do próbek odlewanych, wskazuje to na zwiększoną sztywność kleju w obrębie spoiny.

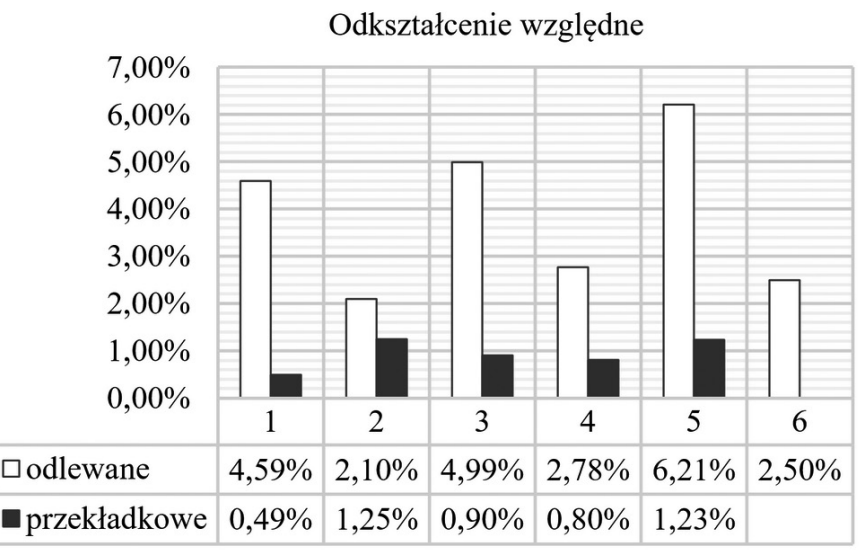

Rys. 7. Porównanie odkształceń względnych kleju w spoinie klejowej oraz w postaci wiosełka

Fig. 7. Comparison of strain of glue in adhesive join and glue in the form of a dumbbell

\section{Podsumowanie}

Analiza studialna oraz przeprowadzony eksperyment pozwolił na sformułowanie następujących, ważniejszych wniosków:

- Przyjmowanie modułu Younga cienkich spoin klejowych na podstawie odlewanej próbki wiosełkowej jest obarczone błędem, związanym z umocnieniem kleju w spoinie w obszarze granicy faz.

- Potwierdzono słuszność przyjętego sposobu badania oraz konstrukcji próbek w celu wyznaczenia pozornego modułu Younga kleju. Zastosowanie kompensacyjnego uchwytu mocującego pozwoliło na otrzymanie powtarzalnych wyników badań, pomimo złożoności w budowie próbki. W ten sposób zachowano jednorodne rozciąganie każdej z 31 badanych spoin.

- Stwierdzono istotne zwiększenie wartości modułu Younga kleju epoksydowego Epidian 57/PAC w próbkach przekładkowych w porównaniu do próbek wiosełkowych. Uzyskane wyniki badań porównawczych dają możliwość zwiększenia dokładności obliczeń symulacyjnych połączeń klejowych metodą elementów skończonych. Uwzględnienie dodatkowego obszaru umocnienia spoiny klejowej, o zwiększonej wartości modułu Younga w strefie przyściennej, będzie skutkować opracowaniem nowego, nieliniowego modelu połączenia klejowego. Model ten będzie uwzględniał zjawiska zachodzące na granicy faz, obejmując wpływ działania sił adsorpcji na usieciowienie kleju.

- Zakłada się, że umocnienie kleju zachodzi tylko dla spoin o bardzo małej grubości. W spoinach o grubości powyżej 0,05 mm zjawisko umocnienia będzie zanikać na rzecz wartości podstawowej modułu Younga. Dla dokładnego określenia głębokości umocnienia kleju, mierzonej prostopadle do łączonych powierzchni, w odniesieniu do grubości spoiny, potrzebne są specjalistyczne badania.

- Dokładne określenie stopnia umocnienia spoin oraz przyjmowanie wyższej wartości modułu Younga spoiny modelowanego połączenia, wpłynie na zmniejszenie niepewności symulacji połączeń klejowych.

- Otrzymane z badań doświadczalnych wartości pozornego modułu Younga znacznie przekraczają wartości teoretyczne wyznaczone z zależności (1).

Przedstawiona metoda doświadczalna może posłużyć do wyznaczenia pozornego modułu Younga kleju w połączeniach innych materiałów. Przedstawiona zmiana wartości modułu Younga dotyczy wyłącznie połączenia klejowego stali 1.4301 łączonej klejem Epidian 57/ PAC.

\section{Literatura}

[1] J. Godzimirski: Wytrzymałość doraźna konstrukcyjnych połączeń klejowych, Wydawnictwo Naukowo-Techniczne, Warszawa 2002.

[2] P. Czub, Z. Bończa-Tomaszewski, P. Penczek, J. Pielichowski: Chemia i technologia żywic epoksydowych, Wydawnictwo Naukowo-Techniczne, Warszawa, 2002.

[3] pod red. C. V. Cagle'a, [tł. z jęz. ang. : Z. Dobkowski]: Kleje i klejenie: poradnik inżyniera i technika, Wydawnictwo Naukowo-Techniczne, Warszawa, 1977.

[4] T. Burakowski, T. Wierzchoń: Inżynieria powierzchni metali, Wydawnictwo Naukowo-Techniczne, Warszawa, 1995.

[5] Adams R.D.: Structural Adhesive Joints In Engineering, Elsevier Applied Science Publishers. London and New York, 1984.
[6] J. Godzimirski, S. Tkaczuk: Określanie właściwości mechanicznych spoin klejowych, Technologia i Automatyzacja Montażu, 3-4/2004, str. 95-97, 2004.

[7] PN-EN ISO 527-4:2000, Tworzywa sztuczne - Oznaczanie właściwości mechanicznych przy statycznym rozciąganiu - Warunki badań kompozytów tworzywowych izotropowych i ortotropowych wzmocnionych włóknami.

[8] PN-EN 15870:2009 Kleje - Oznaczanie wytrzymałości na rozciąganie połączeń czołowych.

[9] J. Kuczmaszewski: Podstawy konstrukcyjne i technologiczne oceny wytrzymałości adhezyjnych połączeń metali, Wydawnictwa Uczelniane Politechniki Lubelskiej, 1995. 